\title{
Unwomanly Woman: How Some Nineteenth-Century British Fictions Imagined Begum Samru of Sardhana
}

Ayusman Chakraborty

https://orcid.org/0000-0003-0641-0652

Taki Government College, West Bengal, India,

\begin{abstract}
In the late eighteenth century India, Begum Samru rose from a dancing girl to become a renowned military adventuress and the ruler of a small semi-independent principality. One of the few female rulers in the country at that period, she is romanticized nowadays in popular histories and biographies. This article examines how three nineteenth-century colonial authors imagined her in their fiction. It shows that these provide counternarratives to contemporary romanticizations of the Begum. By comparing colonial depictions of her with contemporary ones, the article highlights how all such imaginings are informed by the authors' confirmation biases. It finally argues for the need to look beyond the personal life of Begum Samru to fully appreciate the other aspects of her sterling career.
\end{abstract}

Keywords: Begum Samru, imagining, colonial fiction, Scott, Hockley, Blythe Patton.

\section{Introduction}

Sold into prostitution in her infancy, an indigent orphan grows up to become a renowned military adventuress and the ruler of a semi-independent kingdom. This seems so much like the plot of a televised melodrama ${ }^{1}$ or a literary romance. However, truth is often stranger than fiction. One finds that the story of Begum ${ }^{2}$ Samru's life (ca. 1749/50 ${ }^{3}-1836$ ) is indeed astonishing. ${ }^{4}$ Noted for her scandalous past as well as for her meteoric rise from impoverishment and complete obscurity to prosperity and prominence, she became something of a celebrity in her own time. In the words of Viscount Combermere ${ }^{5}$, she was "a kind of Taj Mahal whom no

This open-access work is licensed under a Creative Commons Attribution Noncommercial 4.0 International License. For more information visit https://creativecommons.org/licenses/by-nc/4.0/ 
foreign visitor could afford to miss" (cited in Dalrymple, 15). Indeed, she faded away from public memory in the late nineteenth and the early twentieth century. John Lall ruefully remarks, "Her life and achievements were relegated to obscure records in the archives of India and London ... All was lost and gone" (114). Probably, as Julia Keay suggests, her "past association" with prostitution "became a black mark against her" in that prudish era (32). But there was a revival of interest in Begum Samru's life in the late twentieth century. Today, she is remembered as a "highly romanticized historical figure" (Khan 707) and a feminist icon for her independent and unconventional life.

This paper examines how a few nineteenth-century British fictions had imagined Begum Samru. Through this, it calls attention to the differences between colonial and contemporary reconstructions of her life. While colonial authors decried what they perceived as her gender transgressions, many contemporary authors take interest in her for her challenging gender stereotypes. Particularly, feminists tend to iconize her nowadays. This paper does not seek to validate the foregoing assertions, since these are too obvious anyway. Instead, it demonstrates how both colonial and contemporary authors have imagined her in ways that fit in with their personal beliefs and ideologies. Colonial fiction, as opposed to memoirs, has been chosen for two reasons. Perhaps the artless reason would be that these now-forgotten works have received scanty or no attention so far. These are overlooked artefacts of a bygone age, the discovery of which never fails to raise one's wonder. But the weightier and more pragmatic reason is that literary works, as opposed to memoirs, enjoy greater freedom of invention. In them, a writer is not constrained by facts. Consequently, and somewhat paradoxically, they at times more vocally expose the authors' prejudices than memoirs and histories do. ${ }^{6}$ The latter often try to cloak the authors' own biases to keep up the semblance of objectivity. ${ }^{7}$ However, many contemporary 
reconstructions of Begum Samru's life are visibly more candid about their ideological substratum than their nineteenth-century counterparts.

To show how British colonial fictions imagined Begum Samru, this paper closely reads three nineteenth-century works - Sir Walter Scott's The Surgeon's Daughter (1827), William Browne Hockley’s “The Natch” (1835), and James Blythe Paton’s Bijli the Dancer (1898). The purpose is not to 'rediscover' the 'historical' Begum Samru, which is perhaps impossible. Instead, I simply examine how these colonial authors imagined her in their fictions (emphasis mine). By comparing contemporary reconstructions of her life with these, the article demonstrates how all such narratives are informed by the ideological standpoints of their respective authors. It appears that the imaginings and reimaginings of Begum Samru have less to do with curiosity in her life for its own sake. Rather, authors in all ages have often used her tale to buttress their own ideological convictions.

Without a bit of background information, it would be difficult to understand the extraordinary course of Begum Samru's life and career. Therefore, the next section begins by briefly recounting the story of her life. In the process, it also examines how contemporary authors visualize her. It then moves on to the third section to examine the imaginings of Begum Samru in colonial fictions.

\section{Confronting 'a past shrouded in mystery': Narrating Begum Samru's story in our age}

What makes Begum Samru such an enigmatic figure is the near absence of verifiable information on her early life. As both Alka Hingorani and Amy Marshall have shown, the Begum well understood the value of cultivating a good self-image (Hingorani 54-70; Marshall 172-186). Lall too believes, "[w]ith her it was the public image that mattered" (82). Through the 
paintings of her court painter, Jiwan Ram, and the panegyric in Persian Zebul Tawarikh (1823) ${ }^{8}$ by her $m u n s h i^{9}$ Lalla Gokul Chand, she tried to fashion an identity that would suit her purpose. ${ }^{10}$ Particularly, the work by her munshi, as Amy Marshall recognizes, "can be viewed as personal propaganda and a means for self-promotion" (175). ${ }^{11}$ Given these facts, it is easy to understand why the Begum chose to maintain a discreet silence about her early life in a tawaif ki kotha or a bagino. ${ }^{12}$ Michael H. Fisher even suspects that "[S]he herself may not have known the circumstances or the year of her birth" (The Inordinately Strange, 14). In the absence of reliable biographical data, one must depend on sources that drew their materials from gossips and hearsay. It is germane to note here, that for Begum Samru's life and career, our most reliable sources of information are official correspondences by British officials in India. These are both to and about her. The next best sources of information are travelogues and memoirs written by various European expatriates in India. Among others, one may name the works by 'A.D,'13 Thomas Bacon, Bishop Heber, Colonel James Skinner and Baillie Fraser. ${ }^{14}$ But, as Lall has shown in his "Preface," these are not always reliable (x). Attempts to construct biographical sketches of this august Christian princess in Hindustan were made shortly after her death. Major Sir William Henry Sleeman (1788-1856), famous for his operations against Thuggee, ${ }^{15}$ had devoted an entire chapter to her in his Rambles and Recollections of an Indian Official (1844). Reverend W. Keegan's Sardhana and its Begam (1879) is the first full-length biography of Begam Samru to appear in English. However, these works rely as much on gossips and rumours as on verifiable facts. Consequently, one must use them with caution.

It is possible to construct a coherent account of Begum Samru's life with the available data, although one must acknowledge the gaps and ellipses which can be filled only with imagination and educated guesses. Scholars generally accept that her name was Farzana, though 
we are not sure whether it was indeed her birth name or whether she simply adopted it later (see Fisher, "Becoming and Making 'Family' in Hindustan," 97; Keay 25). It seems that she was born to a Muslim man and his concubine. Her father has been variously named Asad Khan (Smith n.p.; Lall xvii) or Latafat or Lutf Khan (Keay 25). There is, however, the consensus that he was a Saiyad of Arabian origin (Sleeman n.p.; Lall xvii; Keay 25). Her mother's name may have been Zeldah, who was a Kashmiri tawaif ${ }^{16}$ (Keay 25). It is generally accepted that Farzana was born at Kutana, which is near her future jaidad Sardhana. After the death of her father, the newly widowed mother and her infant daughter were thrown out of their home by the stepson (Lall xvii; Keay 25). Left entirely destitute, the mother travelled to Shahjahanabad (now known as Delhi) with her child - presumably to return to her old profession. She vanished from history soon after. The daughter grew up in a kotha in Delhi's Chauri Bazaar, receiving all requisite training in singing, dancing, etiquette and ars amatoria (Lall xviii; Keay 35-36). It is here that she met and conquered the heart of the European mercenary, Walter Balthazar Reinhardt Sombre (ca. 1725 1778). Reinhardt, an Austro-German, was a noted turncoat who served the British, the French, and several other Indian powers in succession. ${ }^{17}$ He commanded a mercenary brigade of his own. Reinhardt had gained infamy as "the butcher of Patna" for massacring a group of British prisoners at the order of Nawab Mir Qassim of Bengal. ${ }^{18}$ Before picking up Farzana, he may have already had several other concubines. ${ }^{19}$ The notable one was Bara Bibi ${ }^{20}$, by whom he had a son. ${ }^{21}$ However, by dint of her charm, sagacity, and shrewdness, Farzana outshone all the other inmates of Sombre's 'zenana'.

A lot has been written on Reinhardt Sombre's relationship with Farzana, who was thirty years her senior (Keay 62). Some like Keay have tried to romanticize it as an ideal relationship between a husband and his wife $(65-68) .{ }^{22}$ However, Lall's estimation appears closer to reality. 
He sees it as a relationship of convenience: "Farzana never left his side, though it would be naïve to see this as devotion rather than loyalty, or as affection instead of a traditional sense of duty" (Lall 11). It is doubtful whether they ever formally married. In a note to Sleeman's Rambles and Recollections, Vincent Smith alludes to the belief that Reinhardt, in his last years, "so completely fell into the hands of the Bēgam that she had no difficulty in inducing him to exchange the title of mistress for that of wife" (n.p.). Whatever the truth is, Farzana must have relished being recognized as Samru ki Begum or Begum Samru - since she retained this title all her life.

With the death of Reinhardt Sombre in 1778, began Farzana's rule over the jaidad of Sardhana. ${ }^{23}$ Michael H. Fisher seems right in using the word improbable to characterize her "six decades of rule" (The Inordinately Strange, 13; emphasis mine). Even in our more 'liberal' age, it is difficult to imagine the transformation of a tawaif to a ruler. What makes it even more impressive is that she faced constant challenges to her rule throughout her life. Immediately after the death of Reinhardt, there was an attempt to transfer the jaidad to his incompetent son. Given that the law of primogeniture usually decided cases of inheritance in that age, the Begum's success in ousting her stepson reveals her unique cunning. Various sources have pointed out that she was popular with the army, having accompanied Reinhardt in action several times (Lall 2324; Keay 66-67). Therefore, the army backed her at this crucial juncture. Her ingenuity also stood her in good stead. Perhaps Lall is right in deducing that she converted to Roman Catholicism mainly to have her marriage with Sombre belatedly legitimized, and thereby, to have "the stigma of concubinage" removed from her (33-34). ${ }^{24}$ If this was indeed so, it was certainly a shrewd move. It might have also been the case, as Pillai has argued, that she converted to Christianity to escape "Islamic restraints on her sex" (106). ${ }^{25}$ However, her rule remained contested throughout her life. The matter headed to a crisis in 1793 when she married 
the French adventurer Le Vassoult. ${ }^{26}$ The insolent husband antagonized everyone in Sardhana, who were already scandalized by this marriage. When the unfortunate couple tried to escape in 1795, they were hotly chased. While Le Vassoult committed suicide, the Begum was dragged back to Sardhana where she was chained to a gun carriage for seven days. Ultimately, it was the bravado of her former paramour George Thomas that saved her. The Begum was reinstated as the ruler of Sardhana. She learnt from her mistake and maintained discretion throughout the rest of her life. The final challenge to her rule came from the British colonizers when they tried to annex her jaidad and pension her off. The catastrophe was averted in 1805 when Sardhana was conferred on her by the British for life. The Begum ruled Sardhana till her death in 1836. Immediately after her funeral, it was formally annexed to British India. ${ }^{27}$

Among other achievements of Begum Samru, mention must be made of her successful military career. As a retainer of the Mughal emperor Shah Alam, she dutifully protected him from his enemies several times; once, it is true, rather belatedly from the psychopathic Ghulam Qadir. $^{28}$ The grateful emperor lavished her with such titles as Zeb-un-Nissa (Jewel among Women), Farzand-i-Azizi (beloved daughter) and Umdat-al-Arakin (Pillar of the State) (Pillai 103). She successfully cultivated the image of a warrior queen who was to be both admired and feared; one who had "allies everywhere, and friends nowhere," as A. D. remarks (cited in Lall 58). She did not ignore her other royal duties either. Her greatest cultural contribution is the construction of the Basilica of Our Lady of Graces in Sardhana in $1822 .{ }^{29}$ She also had some palaces constructed for her. As a self-professed Christian princess, Begum Samru donated lavishly to churches - both Roman Catholic and Protestant ones (for a detailed account see, Khan 715; Fisher 35). ${ }^{30}$ She also patronized Christian missions in India. According to Farha Khan, the Baptist priest Chamberlain "preached for twelve days without intermission at Hardwar" at the 
Begum's encouragement (709). ${ }^{31}$ Begum Samru was a patron of the arts too (Lall $71-75$ ), though this side of her life has received less attention. As an administrator, she was ruthless but efficient. Sardhana apparently prospered during her reign (Lall 68 - 69). She became immensely rich and her principal heir Dyce Sombre was left with a sum of $£ 800,000$ after her death (Lall, Appendix I, 120).

To both her contemporaries and subsequent generations, Begum Samru has remained an enigma. As Fisher points out, people had found, and continue to find her - "alluring, arbitrary, despotic, exotic, nationalistic, pious, romantic, tragic, and/or vindictive" (The Inordinately Strange, 14). What interests one is the various ways she has been represented to fit in with different ideological standpoints. For instance, Catholic campaigners have often projected her as the champion of Catholic Christianity in India; with Pope Gregory XVI even addressing her as his "daughter in Christ" (Fisher 36). ${ }^{32}$ However, some Roman Catholic priests of her age had also condemned her for observing some Muslim practices (Lall 32; Khan 708; Fisher, The Inordinately Strange, 18, 35). Thus, to Catholic writers, she becomes both a champion of the Church and an "artful apostate" (to cite Lall, 113) as the occasion demands. Likewise, the British colonial attitude towards her was ambivalent. As long as an alliance with her was valuable, she was publicly extolled. But the British never fully trusted her. Her mysterious and scandalous past, unconventional habits, unusual dressing, and Roman Catholicism- all made her an outsider to them. As a result, Lall points out, "Meerut was rife with gossip about the old lady" (63). To the majority of British colonizers, she was either a witch or "a sad tyranness" - as Bishop Heber calls her (278). It seems that eighteenth and nineteenth-century British attitudes towards Begum Samru were always governed by self-interest. This is probably why her beneficiaries like Thomas Bacon or W. H. Sleeman continued to represent her in a somewhat favourable manner 
even after she lost importance to the colonial government. Perhaps her fading away into obscurity after her death is not surprising; since the colonizers were left with no reasons to remember her. As far as the Indians are concerned, Begum Samru was lost in a crowd of hundreds of petty semi-independent rulers of her times. Some nationalist historians like Brajendranath Banerji and Mahendra Narain Sharma did try to project her as a somewhat 'patriotic' figure (see Sharma 110, 174). In the twentieth century, only three full-length scholarly works on her life were published. These are Brajendranath Banerji's Begum Samru (1925), Mahendra Narain Sharma's The Life and Times of Begum Samru of Sardhana (1985) and John Lall's Begam Samru: Fading Portrait in a Gilded Frame (1997). It is only with the dawning of the twenty-first century that Begum Samru started receiving public attention once again. Perhaps, this is due to our increased concern with culture and gender identities. Thus, while her breaking of boundaries and taboos have endeared her to some like Alka Hingorani and Garodia Gupta, others like Brijraj Singh and Durba Ghosh have admired her fusion and crossing of cultures (Hingorani 59-68; Gupta sic passim, Singh, "The Enigma of Begum Samru," 35, 40-43; Singh, "Crossing Boundaries," 87; Ghosh 157). To these latter scholars, she becomes a champion of pluralism and cultural experimentation. Julia Keay's attempt to portray her as an Indian woman 'enlightened' through Western contact appears somewhat dated in our age. Her description of the Begum as "the only emancipated Indian female" comes as an evident surprise (15). Not least because, she compares Farzana with another near contemporary 'enlightened' female ruler Ahalyabai Holkar; and, as she admits, not to Farzana's advantage (Keay 99-100). Today, one comes across dozens of features on Begum Samru on the internet. These popular reconstructions of her life usually romanticize her from a feminist perspective. ${ }^{33}$ 
The lack of objectively verifiable information on Begum Samru makes all retellings of her life speculative to a certain degree But what troubles one is the attempts to distort or whitewash known facts to make her image fit in with one's own confirmation bias. Confirmation bias, as Raymond S. Nickerson defines it, is "the seeking or interpreting of evidence in ways that are partial to existing beliefs, expectations or a hypothesis in hand" (175). There is usually an "unwitting selectivity" in "the acquisition and use of evidences" (Nickerson 175). Such confirmation biases usually affect popular retellings of Begum Samru's life. But quite surprisingly, sometimes even more scholarly works fall prey to such confirmation biases. A few examples may be provided. Both Lall and Fisher describe her as a "severe" or a "ruthless" ruler, who exploited her subjects and taxed them heavily (Lall 63; Fisher, The Inordinately Strange, 1; also, Singh, "Crossing Boundaries," 20). ${ }^{34}$ Lall even convincingly argues that she was "highhanded in raising revenue from every imaginable source," since she could not have otherwise amassed a fortune of half a crore from an actual revenue of ten lakhs (82). And yet, the same scholar goes on to portray her as a "bountiful benefactress" who looked after the benefit and welfare of the agriculturists in her kingdom (68-69). Nothing can be more confusing than this. There are also other instances where scholars have either selectively used evidence or whitewashed facts to establish their predetermined views of Begum Samru. For instance, her cruel disposition had earned her much notoriety in her times. Bishop Heber reports that "several stories are told of her cruelty, and the noses and ears which she orders to be cut off" (278). He also recounts the famous story about the dancing girl immured alive, to which we will return later. Lall believes that she was vindictive in nature, as her efforts to ruin her former paramour, George Thomas shows (45). He even feels that the Begum may have had a hand in having a cruel punishment inflicted on Ghulam Qadir for his crimes (Lall 65). Both Lall and Fisher allude 
to the rumour that she faked an injury to drive her husband Le Vassoult to despair and suicide (Lall 44; Fisher, The Inordinately Strange, 20). Apparently, the Begum did this to increase her chances of survival. If this is true, it is nothing but cold-blooded murder. It must be acknowledged that Begum Samru deserves the benefit of doubt since there is no real evidence to incriminate her in this case. But objectivity demands that one mentions it at least if only to refute it later. However, many writers choose to conveniently forget this incident. The most incriminating evidence of Begum Samru's cruelty has been provided by her great-grandson and heir David Dyce Sombre in his diaries. ${ }^{35}$ Fisher informs that the demanding Begum had threatened to poison her ward if he thought of betraying her. To drive home her point, she even made the young boy watch the death agonies of a slave girl whom she had poisoned (Fisher, The Inordinately Strange, 40). It is difficult to believe that David made this up to malign her since he recorded it in his diary and not elsewhere. However, scholars often rationalize or gloss over these atrocities to present a more romanticized picture of Begum Samru. Lall himself tries to explain away her cruelties with the hackneyed reasoning that "enormities of this kind were not unusual in the confusion of the "time of troubles"” (65). Similarly, Farah Khan tries to make light of her iniquities by observing that "the Begum's reputation for such severity worked to her advantage" (714). But one feels that such grounds could be used to rationalize anything from murder to genocide. While academic writings try to rationalize her atrocities, popular histories and romances simply gloss over such facts. Among scholars, only Keay draws our attention to the many Farzanas - the more unappealing ones being "no more hinted at" nowadays $(21-22)$. In a way, such selective presentation of facts in some contemporary writings mirrors the colonizers' practice of narrativizing the colonized - though these ostensibly seek to challenge the latter. 
As stated earlier, this article focuses on three British colonial fictions which (re)imagined Begum Samru. It is not the intention to claim that the authors concentrated on in this article were correct in their estimation of her character. It is easy to see that these colonial narratives were coloured by the authors' prejudices. At the same time, these works do provide counternarratives to some contemporary over-romanticizations of the Queen of Sardhana. To my mind, such narratives and counternarratives show that confirmation bias affects both colonial and postcolonial (re)imaginings of Begum Samru.

The following section examines the three colonial texts to reveal how colonial authors imagined Begum Samru in their fictions.

\section{Colonial imaginings of Begum Samru}

It must be noted at the outset that colonial fictions on Begum Samru are only a few in number. There could be several reasons behind this. The most obvious one is that the colonizing British became disinterested in Begum Samru after she ceased remaining a valuable ally. Besides, there were lots of weightier and more sensational topics for writers to write on: like Indian religious beliefs and customs, the Battle of Plassey, Tipu Sultan, Thuggee, the Sepoy Mutiny, and Indian nationalism. Also, ordinary British readers generally remained uninterested in India and her people throughout the colonial period. Susan Howe believes that India, with its complex society and cultures, posed a difficult intellectual challenge to such readers. It consequently induced a "defeatist state of mind" in the majority of them (Howe 37). Likewise, Edward Farley Oaten admits that the British lacked interest in all things Indian (46). Naturally, a semi-independent ruler of a small principality like Begum Samru could hardly excite any interest in Britain. This is more so since India never lacked its spate of illustrious and more accomplished 
rulers and military adventurers - including female ones. Finally, the colonizing British seems to have harboured some unease about their alliance with the Begum all along. Her mysterious and scandalous past, conversion to Roman Catholicism, cultural experimentation and gender transgressions had all made her an awkward ally. So, the colonial writers of fiction chose to imagine her in the role of an antagonist rather than as a friend to the British.

Sir Walter Scott's The Surgeon's Daughter is the first work to fictionalize Begum Samru. Strangely, till today, only a few have realised that the 'Queen of Sheba' old Mother Montreville or Begum Mootee Mahul in this novel is modelled on the queen of Sardhana. To my knowledge, Vincent Smith is the only colonial historian to have recognized this. ${ }^{36}$ Among the more recent authors to do so, one may mention Brijraj Singh ("Crossing Boundaries," 17). Scott's novel was published in 1827, almost nine years before Begum Samru's death. Understandably, he did not directly name her in his novel. While he does reinvent the origin of Begum Montreville, he also leaves us enough clues to identify her as being modelled on Begum Samru. Thus, Scott's Begum Adela Montreville is the daughter of a Scott sergeant in Comte de Lally's regiment at Pondicherry (Scott 115). He also changes the locale from North to South India, making it further difficult for his readers to associate Begum Samru with Begum Montreville. However, the character is described as the widow of a Swiss or French military adventurer who set up a small independent principality in India (Scott 115 - 119). One detects here an oblique reference to Walter Reinhardt Sombre and his Sardhana. If that is not enough, Scott makes the antagonist Richard Middlemas mention a Circassian rival whom the jealous Begum had had "interred alive" under her seat (Scott 129). Here the author certainly alludes to the infamous rumour that Begum Samru had dispatched a slave girl in this manner, who had become the mistress of one of her paramours. Both Vincent Smith and Briraj Singh recognize this. 
In Scott's novel, Begum Montreville plays the role of a minor antagonist. She is a military adventurer who joins Hyder Ali and his son Tipu Sultan in their fight against the British. This is ironic, as Begum Samru had been a faithful ally to the colonial government. Perhaps Scott's imagining her in the role of an enemy shows that the British public mistrusted her nevertheless. In the novel, Begum Montreville plots with Richard Middlemas to hand over Menie Gray, Richard's lover and the daughter of his former benefactor, to Tipu Sultan. While Scott's characterization of Tipu as a lustful Oriental despot has already received sufficient attention (see for instance Chatterjee 186-187; Chakraborty 58), the Begum has largely escaped notice. Of the few scholars who have ever paid any attention to her, the majority have accepted her as a completely original character. For instance, failing to realize that she is based on Begum Samru, Upamanyu Pablo Mukherjee concludes that "[i]n Mrs Montreville, Scott reverses the colonial stereotyping of Indian female sexuality, and attaches those signs to the European woman" (68). ${ }^{37}$ This mistake enables him to read The Surgeon's Daughter as a covertly anticolonial text which highlights the pitfalls of colonialism - including its 'unsexing' of European women. It must be acknowledged that taken as a self-contained text, the novel might appear to support Mukherjee's deconstructive reading. However, read in conjunction with other nineteenth-century British writings on Begum Samru, Scott's work reveals a peculiar trend of imagining her. It turns out that colonial writings often unsexed Begum Samru to present her as an 'unwomanly woman'. Michael Fisher draws our attention to some British memoirs which did this ("Becoming and Making," 105, 119). In keeping with that trend, Scott presents Begum Montreville in his novel as an "unsexed woman" - an "Amazonian Princess" with "masculine notions and expressions" $(125,129,127)$. She boasts, "I am a woman ... but one who wears a dagger ... I am a woman who has looked on ... dying men" (Scott 128). Scott suggests that her 
participation in 'masculine' activities has turned her into a freak. Middlemas himself calls her a devil (Scott 127). One character in the novel mentions that she had probably betrayed her first husband and had him killed, though Scott quickly makes another character refute this rumour (Scott 117, 119). Evidently, here he had in mind the rumour about Begum Samru getting rid of her troublesome second husband Le Vassoult through cunning. Scott seems to attribute all Begum Montreville's iniquities to her deliberate unsexing of herself. The novel indicates that she wanted to force Menie Gray into sexual slavery not simply to gain the favour of Tipu Sultan. Jealous of Middlemas' love for her, she wanted to have her rival permanently ousted. However, her infatuation for Middlemas is also shown to be shallow, since she not only betrays him in the end but also laughs hysterically when he is cruelly executed by the orders of Hyder Ali (Scott 115). ${ }^{38}$ All these mirror the cruelties and selfishness that Begum Samru was accused of. It appears that the author tacitly criticizes her transgression of gender norms. We shall see that subsequent colonial writers follow him in this.

William Browne Hockley's short story “The Natch” was anonymously published in 1835, just a year before Begum Samru's death in 1836. This work has received very little attention. Only Michael Fisher names it in one of his notes, though he pays no further attention to it (The Inordinately Strange, 329). Unlike Scott, Hockley does not conceal the identity of his character even though she was still alive. Maybe, it is because the work was published anonymously. Moreover, the author was too prejudiced against the Indians, in general, to care for anyone's feelings. William Browne Hockley (1792 - 1860) served as an assistant judge in British India for ten years. He was charged with corruption. Though acquitted in 1823, he left India in disgrace with a pension of 150 pounds per annum (H-Shihan 47). Even from the little known about him, it is clear that he harboured a grudge against the Indians. Probably, he held them responsible for his 
downfall. Being bitterly critical of entire India, he freely expresses his prejudices against the Begum whom he portrays as an inhuman monster.

Hockley's story is based on a purportedly real incident, one which has earned Begum Samru everlasting notoriety. In fact, there are several versions to it. Bishop Reginald Heber (1783 - 1826), one of the earliest writers to record it, reports that the Begum had one of her "dancing girls" immured alive for offending her. Afraid of any rescue attempt, she had her bed placed directly over the underground chamber in which the girl was buried alive. She then slept on that bed for consecutive nights till the victim below died of starvation (Heber 278 - 279). However, one must note that Heber hesitates to place absolute trust on this report derived from gossip (Heber 278). W. H. Sleeman (1788-1856) also relates this incident in his Rambles and Recollections, though his version is very different from Heber's. Sleeman writes that two slave girls in her service had run away with two of her soldiers. To cover their tracks, they had set fire to her mansion at Agra. There was a "great loss of property" from the conflagration. To give them exemplary punishment, the Begum had them flogged senseless, and then "thrown into a pit dug in front of her tent for the purpose, and buried alive" (Sleeman n.p.). Writers, who prefer to romanticize Begum Samru, accept this version as the accurate one. Both John Lall and Farah Khan try to explain away her action as arising out of the necessity of quelling insubordination among her troops (Lall 26 - 27; Khan 714). Lall also feels that the details may have been later “enlarged upon" (26). Michael Fisher, usually circumspect in other matters, also accepts this version of the story and the rationale offered for it (The Inordinately Strange, $39-40) .{ }^{39}$ So does Julia Keay (96-97). Strangely, no one has considered till now that Sleeman may have had personal reasons for whitewashing the deed. He had enjoyed the hospitalities of Begum Samru and was a friend to her heir. Later, he even held the power of attorney for David's Indian 
possessions and was also the co-executor of his will (Fisher, The Inordinately Strange, 30). A known opportunist, Sleeman can hardly be trusted where his self-interests were involved. Vincent Smith, while annotating Rambles and Recollections, mentions a still different version of this incident in his note. He alludes to the rumour that the girl was punished in this gruesome manner for drawing the "favourable notice of one of the Bēgam's husbands" (Smith, Rambles and Recollections, n.p.). Lall too refers to this version, if only to hastily dismiss it (64 - 65). Thus, it is interesting to note how this incident has been described in different ways to fit in with the authors' confirmation biases. One may also see that the version mentioned by Smith is more in line with Scott's imagining of this incident. Hockley too imagines it similarly.

In "The Natch," Tarzah and Codend are lovers in Begum Sumroo's (sic) service. When the jealous Begum discovers their love for each other, she has the dancing girl Tarzah immured alive in a small chamber under her hall. She then sleeps on the top of it till her victim dies. The Begum inflicts this extreme punishment on Tarzah for two reasons:

As a queen, the begum was eager to revenge the insult to her power, - as a woman, her whole soul burned to destroy the beauty which had tempted a favoured one to despise her won. (Hockley $172-173$ )

Thus, like Scott, Hockley sees the Begum as being driven by sexual jealousy. Notably, she is shown to have raised Codend from a lowly position to her chief of guards (Hockley 161, 167). The story thus hints that she was sexually interested in him. Interestingly, among our contemporary authors, Jaipal Singh's retelling of this incident somewhat resembles Hockley's. In Singh's novel, Begum Samru becomes jealous when she finds a slave girl kissing her paramour 
George Thomas (93). But craftily, Singh rationalizes her subsequent cruelty as originating in her midlife crisis. Hockley, on the other hand, summarily condemns her as "the woman-fiend" (176).

From the brief outline of the plot provided, one may easily surmise how Hockley imagined Begum Samru. He depicts her as a cruel despot:

[S]he carried her despotism to the very verge of human sufferance, and perpetrated atrocities which fortunately in this age can stain the annals of no monarch but an oriental or a Russian. (Hockley 163)

Like Scott before him, he sees her as an "unwomanly" woman - one who did something "so darkly cruel" which could not have been done "by woman to woman" (Hockley 170, 172). In her vengeance, she is thus rendered inhuman. In fact, Hockley compares her to a boa with "a bright, but cold gaze" (169). Though he does praise her great courage, he also depicts it as something perverted since it is "far beyond that which characterises the generality of the stronger sex in India" (Hockley 162- 163). One may note how both Scott and Hockley unsex Begum Samru to present her as an abnormal woman. Clearly, it is her so-called gender transgressions that these writers find so detestable.

Finally, we turn to James Blythe Patton's novel Bijli the Dancer. ${ }^{40}$ Unsurprisingly, this novel has failed to draw the attention of scholars researching on Begum Samru. The work is not actually about her. She is mentioned just twice in it. But the context in which she is mentioned in this novel is very significant. It shows how ordinary British people remembered her at the turn of the century. The novel itself is an uncommon one. It depicts the romance between the aristocratic landlord Nawab Bahádur Khan of Ronáhi and the beautiful dancing girl Afránan, nicknamed bijli or lightning. However, this is not a conventional sentimental romance. Afránan is torn between 
her love for Bahádur Khan and her dedication to dancing. She is above all else an artist committed to her art. Bahádur Khan, on the other hand, is torn between his passion for Afránan and his duties as a noble. In the end, Afránan takes the unconventional decision of abandoning her noble suitor for the sake of her art. To do this, she resists the lures of power, status and even respectable family life. In the late nineteenth century, such a decision must have appeared somewhat bold and scandalizing to the readers. It is while making her choice that Afránan thinks about Begum Samru. She is not directly called so in the novel. Instead, she is referred to as "the dancer who had become Queen of Sardhana" (Patton 181) or the "Kanchani Queen of Sardhana" (Patton 165). The author calls her Zainab, which might be a corruption of her title Zeb-un-Nissa (Patton 164). Or, he may have simply made a mistake here. He also reimagines her as the widow of a Pathan noble who later married a European soldier in her service. ${ }^{41}$ Anyway, Afránan draws a parallel between her situation and that of Begum Samru. To her, she appears as a failed artist who betrayed her art for mere wealth and power. Afránan reflects, "she was no singer at heart" (Patton 164). There is again the allusion to the slave girl whom the Begum had buried alive (Patton 164). However, unlike Scott and Hockley, Patton provides a very uncommon rationale for her action. He does not see her as acting out of sexual jealousy. Instead, he feels that her cruelties had their origin in her frustration as a failed artist. Afránan reflects:

[T]hat Kanchani Queen of Sardhana - she had sung and danced in the assembly and knew the joy of freedom, and this was that made her a she-devil. The galling of the bonds - it was that made her mad. What wonder? (Patton 165)

Among other things, it is this consideration that ultimately compels her to leave Bahádur Khan even though they are in love with each other. While the novel perceptibly glorifies Afránan's passion for dancing at Begum Samru's expense, it also marks a departure from the conventional 
portrayal of her as a bloodthirsty tyrant. However, this does not necessarily imply that the novel is a feminist text. One may note that it stereotypes professions like dancing and ruling as being suitable for different genders. It is ultimately Begum Samru's supposed gender transgression that Patton disapproves of, although he does it very cunningly.

Examination of these three nineteenth-century fictions thus reveals some interesting points. First, nineteenth-century British authors often demonized Begum Samru in their works. Secondly, it was her supposed gender transgression that drew their ire. These two facts are interrelated. Notably, these authors did not condemn her for any other transgressions like class or cultural transgressions. Quite surprisingly for the Victorians, none of them made any fuss about her concubinage to Reinhardt Sombre. Instead, all had reimagined her as being legally married to someone. Why did these colonial authors criticize only what they perceive as Begum Samru's gender transgression? Perhaps, Durba Ghosh is right in surmising that by "unsettling" gender identity, she "created a sense of confusion" for the Europeans (160). ${ }^{42}$ This probably made them inimical to her. Whatever the case might be, there exists a similarity in approach between these authors and some of our contemporary ones. Just as these colonial authors had stereotyped Begum Samru as a 'masculinized' woman, some of the contemporary ones romanticize her as a feminist icon. In both cases, Begum Samru is (re)imagined in keeping with the author's own confirmation bias.

\section{Conclusion}

Was she an 'unwomanly woman' or a female ruler ahead of her times? Discussions on Begum Samru seem to have focused on her character all along. While some like Hingorani or Mrinalini Rajagopalan have focused on the paintings or the buildings commissioned by her, such 
discussions have always returned to an assessment of her personality. Perhaps, this is inevitable to an extent. But I feel that an overemphasis on her personal life has drawn away our gaze from other important aspects of her career. As a result, these have received only erratic treatment from scholars. One may note how little we know about the following topics: her efforts to transform Sardhana into a Roman Catholic hub, her management of her large household ${ }^{43}$, her finances and administration of her estate, and the maintenance and disciplining of her army. These have received inadequate attention, if at all. For instance, only Mahendra Narain Sharma has studied her administration in detail (133 - 157). Likewise, I could find only one article by Preeti Sharma on Begum Samru's army. The focus is mainly on her personal life; perhaps because, as Briraj Singh perceptively observes, "Her life could have been scripted for a Bollywood film" ("The Enigma," 34-35). However, excessive concentration on her personality makes one either demonize or romanticize her. In the process, we lose sight of other aspects of her life and career that demand greater attention.

A curious fact about Begum Samru is that she has received more attention from writers of popular histories than academic historians till now. It cannot be denied that this has resulted in having her rehabilitated in the public imagination in our age. But the downside of it is that it is a romanticized version of Begum Samru whom one encounters in contemporary popular histories. In drawing attention back to some nineteenth-century imaginings of her life, this article has tried to highlight a different version of Begum Samru than the ones constructed by contemporary authors. It is not argued that anyone version is truer than the other. But this article stresses the need to recognize that all versions of her can only be constructions. Perhaps, this recognition can lead future scholars to look beyond her personal life and focus on issues that hitherto remain unnoticed. 


\section{Endnote}

1. Begum Samru does appear as a character in the period drama Beecham House (Ahlawat n.p.). Lara Dutta plays her role in this production.

2. Also spelt as 'Begam' in some texts. This article retains the spelling Begum throughout, except in citations.

3. According to Julia Keay's estimate (25). Alka Hingorani believes that she was born in 1750/51 (55). But Vincent Smith mentions in a note that she was born in 1753 (Sleeman, Rambles and Recollections, n.p.)

4. Julia Keay's remark is very apposite - "Fairy tales come no better" (63).

5. Stapleton Cotton, $1^{\text {st }}$ Viscount Combermere, was the British commander-in-chief in India or the supreme commander of the British Indian Army from 1825 to 1830 (Dalrymple 15).

6. There is the added consideration that to achieve commercial success, popular fictions like these catered to public prejudices and showed the public what it wanted to see. Therefore, these often become indices to public opinion.

7. John Lall also believes that memoirs and travel accounts of that period "generally eschewed fiction in favour of reliable fact" $(\mathrm{x})$.

8. While Marshall gives 1823 as the date of composition, Keay writes that it was composed in 1822 and revised in 1853 (Marshall 175; Keay, 24).

9. A munshi is a "court secretary" (translated by Marshall, 175).

10. Hingorani studies Jiwan Ram's portraits of Begum Samru to show how she used these to construct her image as a ruler. Marshall focuses on both the portraits and the biographical poem in Persian. 
11. Parts of it were dictated by Begum Samru to her munshi. That gives us sufficient ground to believe that the Begum exercised some control over the narrative (see, Marshall 175).

12. Lall also draws our attention to this fact, saying "Farzana herself preserved an understandable reticence about her early years" (11). Likewise, Fisher believes that she deliberately "obscured her background and age" (The Inordinately Strange Life,14; see also, "Becoming and Making," 97).

13. A.D. was the initials of Ann Deane (Fisher, The Inordinately Strange Life, 25). Her travelogue gives us a first-hand description of Begum Samru.

14. For this information, I am indebted to Lall and Marshall (Lall 26-28; Marshall, 175).

15. Sleeman is remembered today mainly for launching a crusade against the so-called thugs of India.

16. A tawaif was not only a prostitute but also an entertainer and performer. Keay rightly compares the best among them to the Japanese geisha (29).

17. There exists some confusion regarding Sombre's nationality. Lall believes that he was an Austrian, but Keay points out that, as a native of Alsace, he was as much German as French (Lall 7; Keay 43). Reinhardt changed his surname frequently - from 'Somers' to 'Sombre,' as the situation called for (Keay 47). It was the Indianized 'Samru' that ultimately prevailed.

18. The Patna Massacre occurred on $6^{\text {th }}$ October 1763 when 45 members of the East India Company, including the infamous head of the Patna factory William Ellis, were butchered by Samru and his men under the orders of Mir Qassim (for details see Keay 51 $-53)$. 
19. Some believe that Reinhardt kept a 'zenana' or an establishment of concubines (Lall 12; Ghosh 154).

20. Bara Bibi, as the title suggests, was the senior lady in the household. Little is known about her, except that she suffered from insanity and died in 1838 . Vincent Smith names her Bahā (Bahar?) Begum (Sleeman, Rambles and Recollections, n.p.; also, Singh, "Crossing Boundaries," 14). She might have also been called Moti Begum (Fisher, “Becoming and Making," 98).

21. The son was christened Aloysius Louis Balthazar and inherited the title Zafaryab Khan from Shah Alam.

22. This is also the tone of Jaipal Singh's 2004 novel Samru: The Fearless Warrior.

23. Sardhana, 22 kilometres north of Meerut, was granted to Reinhardt in $1776 / 77$ to maintain himself and his army. According to Lall, it was granted as a jaidad or rent-free land and not as a jagir (20-22; see also, Ghosh, footnote, 153).

24. Farzana was baptized on 7 May 1781 as Joanna. Lall further guesses that the conversion was meant to elevate her status - "She became something other and thus superior" (31). Today, her conversion is sometimes read as an exercise in multiculturalism. The entire debate is deftly summed up by Fara Khan (708-709).

25. I hesitate to accept this line of reasoning since there were other Muslim female rulers, both before and after, who successfully overcame 'restraints' without changing religion. As examples, one might think of Chand Bibi and the Begums of Bhopal.

26. She added "Nobilis" to her name on this occasion (Lall 42).

27. This brief outline of Begum Samru's life cannot relate to all the troubles that she underwent during her long rule. Interested readers may consult the works of John Lall, 
Julia Keay and Michael H. Fisher for details. Smaller accounts of her life can be found in Briraj Singh's “Crossing Boundaries,” Manu S. Pillai’s The Courtesan, the Mahatma and the Italian Brahmin (2019) and Archana Garodia Gupta's The Women who ruled India (2019).

28. Ghulam Qadir was a psychopathic Rohilla chief who took terrible personal vengeance on the aged Mughal emperor Shah Alam by having his daughters publicly stripped and raped before his very eyes, killing his sons, and finally having his eyes gouged out. Though he tried to buy off Farzana, she remained loyal and helped the Marathas to drive him out of Delhi (for a detailed account see Keay 152-170).

29. For a detailed description of the church, as it stands now, one may consult Ashok Ahlawat's article in The Hindu.

30. Farah Khan, Michael Fisher and several others have alluded to the belief that she also donated money to Hindu and Muslim religious institutions (Khan 713; Fisher 17). But Khan also admits that "it has not been possible to find a detailed description of her benefaction to any religion other than Christianity" (713).

31. Fisher informs that the British East India Company forced Begum Samru to expel Chamberlain, fearing that his fanaticism will give rise to religious conflicts in their territory (39).

32. Fisher mentions that she did want to make Sardhana "a major centre of global Catholicism" (36).

33. For instance, one may consider Shreya Ila Anasuya'spiece in Firstpost, Richa Thakur's in Feminism in India, and Sejal Agarwal's in Yahoo! Life. 
34. Singh's defence, which ultimately condenses to the proposition that if she had done it others had done it too ("Crossing Boundaries," 20), epitomizes the sophistic handling of the Begum's story in our age.

35. David Ochterlony Dyce Sombre (1808 - 1851) was the son of Julia Ann Reinhardt, the daughter of Aloysius Reinhardt or Zafaryab Khan. For a detailed account of his life, one should see Fisher's The Inordinately Strange Life.

36. See Smith's second footnote to Sleeman's chapter on Begum Samru in Rambles and Recollections (Smith, Rambles and Recollections, n.p.).

37. Strangely, Mukherjee fails to associate Begum Samru and Begum Montreville, since he refers to the story about the slave girl in an earlier chapter (Mukherjee 43).

38. At the end of the novel, poetic justice overtakes Begum Montreville. Hyder forces her to pay huge compensation to Menie Gray. Her "forts and government" are also appropriated by Hyder and she dies by poison soon after (Scott 151).

39. Although, we must admit that Fisher does not attempt at all to whitewash her atrocities like the others.

40. James Blythe Patton is the pen name of Edmund White (H-Shihan 333).

41. While the "Farangi" (European) soldier is no doubt Le Vassoult, why did Patton reimagine her as being married to a Pathan nobleman? Is it because no proof of her marriage with Reinhardt exists? Was that the reason why he did not call her Begum Samru in this novel?

42. However, I do not wholly agree with Ghosh's point about her 'unsettling' cultural identity since none of these authors focuses on her cultural transgression (Ghosh 160).

43. Michael Fisher's work on Dyce Sombre does provide us with some insight into this topic. 


\section{Works Cited}

Agarwal, Sejal. "Read About Begum Samru, A Nautch Girl who went on to be one of the most Powerful Women in Mughal India." Yahoo! Life, 29 Jan. 2021. https://in. style.yahoo.com/read-begum-samru-nautch-girl-163126976.html.

Ahlawat, Ashok. "The tale of Begum Samru and the Church she built." The Hindu, 11 Sept. 2019. https://www.thehindu.com/life-and-style/travel/the-tale-of-begum-samru-and the church-she-built/article29391513.ece.

Anasuya, ShreyaIla. "Dastaan-e-Dilrubai: The life and times of Farzana Joanna Nobilis Sombre Zeb-un-nissa, or Begum Samru.” Firstpost, 24 June 2020. https://www.firstpost.com/ long-reads/dastaan-e-dilrubai-the-life-and-times-of-her-highness-farzana-joanna-nobilissombre-zeb-un-nissa-or-begum-samru-8489661.html.

Chakraborty, Ayusman. "That disgrace in Human form': Tipu Sultan and the Politics of Representation in Three $19^{\text {th }}$ Century English Novels." Rupkatha Journal on Interdisciplinary Studies in Humanities, vol. 5, no. 1, 2013, pp. 55 - 66. http://rupkatha.com/V5/nl/06_Tipu_Sultan.pdf.

Chatterjee, Amal. Representations of India, 1740 -1840: The Creation of India in the Colonial Imagination. Macmillan Press Ltd, 1998.

Dalrymple, William. "Foreword." Farzana: The Woman who saved an Empire. By Julia Keay, I. B. Tauris\& Co Ltd, 2014, pp. 6 - 12.

Fisher, Michael H. "Becoming and Making 'Family' in Hindustan." Unfamiliar Relations: Family and History in South Asia, edited by Indrani Chatterjee, Permanent Black, 2004, pp. $95-121$. 
---. The Inordinately Strange Life of Dyce Sombre: Victorian Anglo-Indian MP and 'Chancery Lunatic'. Hurst \& Company, 2010.

Ghosh, Durba. "Lives of contrast: Begum Samru and Begum Bennett." Sex and the Family in Colonial India. Cambridge University Press, 2008, pp. 147 - 163.

Gupta, Archana Garodia. "The Dealmaker. Begum Samru." The Women who ruled India: Leaders, Warriors, Icons. Hachette India, 2019, pp. 221 - 232.

H-Shihan, I. Anglo-Indian Fiction: A Brief Outline. Power Publishers, 2016.

Heber, Reginald. Narrative of a Journey through the Upper Provinces of India, From Calcutta to Bombay, 1824 - 1825, vol. II. John Murray, 1838.

Hingorani, Alka. "Artful Agency: Imagining and Imaging BegamSamrū." Archives of Asian Art, vol. 53, 2002/2003, pp. 54 - 70. JSTOR, https://www.jstor.org/stable/20111304.

[Hockley, William Browne]. "The Natch.” The English in India and Other Sketches, vol. II. Longman, Rees, Orme, Brown, Green, and Longman, 1835, pp. 159 - 177.

Howe, Susanne. Novels of Empire. Columbia University Press, 1949.

Keay, Julia. Farzana: The Woman who saved an Empire. I. B. Tauris\& Co Ltd, 2014.

Khan, Farah. "Begum Samru of Sardhana: Socio-Political Interventions and Continuing Legacy.” Proceedings of the Indian History Congress, vol.73, 2012, pp. 707 - 718. JSTOR, https://www.jstor.org/stable/44156266.

Lall, John. Begam Samru: Fading Portrait in a Gilded Frame. Roli Books, 2012. 
Marshall, Amy. "Unconventional Subjects: A very British approach to dealing with extraordinary people considered through a portrait of the Begum Samru, by Jiwan Ram, and The History of Zeb-ul-Nissa the Begum Samru of Sardhana, a poem by LallaGokul Chand.” Unpublished Draft. https://open.conted.ox.ac.uk/sites/open.conted.ox.ac.uk/ files/resources/Create\%20Document/Unconventional\%20Subjects_Amy\%20Marshall.pd f.

Mukherjee, Upamanyu Pablo. Crime and Empire: The Colony in Nineteenth-Century Fictions of Crime. Oxford University Press, 2003.

Nickerson, Raymond S. "Confirmation Bias: A Ubiquitous Phenomenon in Many Guises." Review of General Psychology, vol. 2, no. 2, 1998, pp. 175 - 220, DOI: 10.1037/10892680.2.2.175.

Oaten, Edward Farley. A Sketch of Anglo-Indian Literature. Kegan Paul Trench Trübner \& Co. Ltd., 1908.

Paton, James Blythe. Bijli the Dancer. British Library Historical Print Editions, n.d.

Pillai, Manu S. "The Courtesan who became a Princess." The Courtesan, the Mahatma \& the Italian Brahmin: Tales from Indian History. Context, 2019, pp. 103 -108.

Rajagopalan, Mrinalini. “Cosmopolitan Crossings: The Architecture of Begum Samrū.” Journal of the Society of Architectural Historians, vol. 77, no.2, 2018, pp.168 - 185, DOI: 10.1525/jsah.2018.77.2.168.

Scott, Walter. The Surgeon's Daughter. Serenity Publishers, 2012.

Sharma, Mahendra Narain. The Life and Times of Begam Samru of Sardhana. Vibhu Prakashan, 1985. 
Sharma, Preeti. "The Army of Begum Samru." International Journal of Novel Research in Humanity and Social Sciences, vol. 2, no. 6, 2015, pp. 64 - 67. www.noveltyjournals.com

Singh, Brijraj. “Crossing Boundaries.” Manushi, no. 87, 1995, pp. 13 - 22.

---. "The Enigma of Begum Samru: Differing approaches to her life." India International Centre Quarterly, vol. 24, no. 4, Winter 1997, pp. 33 - 43. JSTOR, https://www.jstor.org/stable/23002292.

Singh, Jaipal. Samru: The Fearless Warrior. Srishti Publishers \& Distributors, 2004.

Sleeman, William Henry. Rambles and Recollections of an Indian Official, edited and annotated by Vincent Smith, Project Gutenberg Ebook, 2005. https://www.gutenberg.org/files/15483/15483-h/15483-h.htm.

Thakur, Richa. "Begum Samru: Nautch Girl Turned Queen of Sardhanal\#Indian Women in History." Feminism in India, 16 March 2017. https://feminisminindia.com/2017/03/16/begum-samru-essay.

\section{Acknowledgement:}

I am grateful to Dr Daniela Radler for giving me the idea for this paper and her continued encouragement.

\section{Bionote:}

Dr Ayusman Chakraborty, Assistant Professor of English (West Bengal Education Service), is currently posted at Taki Government College, Taki, West Bengal, India. For his doctoral degree, Dr Chakraborty researched the life and works of the nineteenth-century colonial writer- 
administrator Captain Philip Meadows Taylor. He is a recipient of Junior Research Fellowship (JRF) and Senior Research Fellowship (SRF), under the West Bengal State Fellowship Scheme. In 2013, he was awarded the Sir Charles Wallace India Trust (CWIT) Research Grant. Dr Chakraborty has written twenty-one research articles and three book reviews, which have been published in various edited volumes and national and international journals. He can be reached at chakar08@yahoo.com

ORCID ID: https://orcid.org/0000-0003-0641-0652

\section{Open Access:}

This article is distributed under the terms of the Attribution-NonCommercial 4.0 International (CC BY-NC 4.0) (https://creativecommons.org/licenses/by/4.0/) which permits any use, reproduction and distribution of the work without further permission provided the original work is attributed as specified on the Transcript: An e-Journal of Literary and Cultural Studies. For more information log on to http://thetranscript.in/

\section{Conflict of Interest Declaration:}

The author declared no potential conflicts of interest about the research, authorship and publication of this article.

(C) Author 